\title{
Rural Household Strategies for Expropriated Land: A Case Study of Demirci Village
}

\author{
Şefika Aydın \\ Namik Kemal University, Vocational School of Social Sciences, Tekirdağ, TURKEY
}

Received: 14 March 2020 • Accepted: 28 May 2020 • Published Online: 20 July 2020

\begin{abstract}
In 2017, it was decided to move the military troop from the capital city Ankara to the PolatlıSivrihisar districts line. Residents of Demirci village, located in Sivrihisar, have been faced expropriation of their lands because of this decision. This study is focused on the household strategies developed by the villagers as a result of expropriation. This study aims to address the changes in the village from a sociological perspective. In this context, interviews have been carried-out with 20 people, whose lands have been expropriated. The collected data has been analyzed descriptively. This study finds that the villagers, who have become landless, tend to migrate to cities. And the material provisions, which have been obtained from the expropriated lands, are generally used non-productively by them. This study also highlights a social disintegration caused by land expropriation in the village.
\end{abstract}

Keywords: expropriation, migration, rural areas, household strategies.

\section{Introduction}

Expropriation of rural areas causes a rapid change in villages (Konak, 2002; Wei, 2011; Feldman \& Geisler, 2012). As a result of the loss of land that provided livelihood, households are obliged to develop new strategies (Ghatak \& Mookherjee, 2014; Cao et al., 2008; Orhan \& Gök, 2016; Öner, 2004).

According to Redclift (1986: 219), the term "strategy" refers to a long-term perspective, which helps the actors to make informed decisions. The strategy is seen as an adequate metaphor to understand whether actors associate their actions with social change at the macro level and to evaluate their responses to structural obstacles and stressful events (Moen \& Wethington, 1992: 233; Wallace, 2002).

In this article, the concept of "household strategy" is used to analyze the behavior of villagers at micro level. This study aims to explore villagers' responses towards expropriation, their investment and immigration decisions towards the city, their perspectives on agricultural production and animal husbandry, and the change in social relations among them.

This study is based on the idea that various social and cultural contexts, where locally developed strategies are formed, must be taken into consideration (Wallace, 2002: 276; Hajdu, 2006). Therefore, although the main focus of the study is locally developed household strategies, the study attempts to establish connections with structural factors to explain the topic. For this, the study first gives space to the literature related to the process of change and expropriation in

(c) Authors. Terms and conditions of Creative Commons Attribution 4.o International (CC BY 4.0) apply. Correspondence: Şefika Aydın, Namık Kemal University, Vocational School of Social Sciences, Tekirdağ, TURKEY. E-mail: sefikaaydin@nku.edu.tr. 
Turkey's countryside in the context of the phenomenon of migration then evaluates the results of the field research that has been conducted in Demirci village.

2. Rural social change in the context of the phenomenon of internal migration in Turkey

Turkish people's migration, from the country's rural areas to cities, have increased in the post-World War II period. The transition to a multiparty movement in Turkey, following World War II and the Marshall Plan that had been implemented in the 1950-1953 and 1960-1972 periods, are important elements that have impacted the rural change. On one hand, the Marshall Plan has made villages more livable to some degree. On the other hand, it has also gradually increased the workforce requirements in the industrial and construction sectors. In addition, the mechanization in agriculture after the 1950s together with other agricultural developments, has rapidly expanded arable areas. This growth; however, along with the growth in population, has caused the transformation of the traditional land system. The polarization between large landowners with small landowners and landless peasants has increased. Many villagers, who have been unable to maintain their agricultural activities, have begun to migrate to cities. Meanwhile, the improvements have provided them transportation facilities and their means of communication have increased. These developments have helped the rural people to experience a modern urban life. "Going to the cities" became quite common in the stages following this process, and thus migration became institutionalized (İçduygu et al., 1998: 221-222; Pamuk, 2009: 68).

Global economic policies have also been effective at reducing the rural population. Commodification, in the Turkish agriculture, has deepened in the globalization process, and this situation has significantly changed the farmers' lives. This structure, which has been created through global trends and comprehensive state-support policies, has eliminated the villages' customary information, production, and marketing networks. New institutions have emerged in the globalization process that establish ties between small manufacturers and larger markets. State policy strengthening of this function in the market has also created fluctuations in cost and demand, and thus small producers are defenseless against the market forces and their levels of risk and increased insecurity (Keyder \& Yenal, 2011: 60; İçduygu et al., 1998: 226; Ecevit et al., 2009: 50). In fact, when examining policies on villages and villagers, although developing policies that show continuity toward villages and villages have not been possible during and prior to the planned period that began in the 1960s, some important steps were seen to have been taken. However, the failure to develop the Government's programs and development plans for villages and villagers has been persisting since 1980, leaving villagers' problems unsolved in Turkey (Kayıkçı, 2004: 2). ${ }^{1}$ Thus after 1985, the rural population in Turkey, has started to shrink in an absolute sense. Price-support programs have diminished, subsidies have been removed, and agricultural manufacturers continue to face with the market. The transition, from the marketprotection policies to a market-dominated structure, have coincided with the self-sufficient villagers simultaneously, who have begun to separate from the land. Therefore, although great differences have appeared among the geographical regions in Turkey, the process of purifying from being a villager has accelerated in the 1980s, and this process is still continuing to date (Keyder \& Yenal, 2011: 61).

Revealing what is actually happening about the movement of people, from rural to urban areas, clearly requires more diverse and different perspectives than macroeconomic factors

${ }^{1}$ In 1980 , the Government in Turkey prepared a packet known as the January $24^{\text {th }}$ Decisions. Thus the economy in Turkey had become completely subjected to the control of the IMF, and new liberal practices started to dominate in the country (Keyder \& Yenal, 2011: 65). 
at the national level. The results from recent research draw attention in this respect. According to Öztürk, Toploğlu, Hilton and Jongerden (2018: 518-521) financial difficulties and poverty are seen as the main reason for migration. Some other common reasons that can be added to the reasons here are: being with family for women, children, and the elderly; marriage for women; finding work, social environment, and better education opportunities for youths; and health issues for the elderly. According to Bıçkı (2011: 178), even though the rural people have been provided the opportunity for sufficient income, they are able to gravitate toward migration.

Village populations vary seasonally, especially as those villagers working in cities, return to their villages in summer months for holidays. This activity, which mostly takes the forms of resting, vacationing, and being engaged in agriculture in the summer months, sustains the villages' vitality for several months (Öztürk et al., 2018: 516-517; Şenol, 2018: 416). However, this situation cannot prevent the standstill of reproduction process on livelihood-oriented villages that are aging and whose population has decreased through migration.

\section{Rural expropriation and displacement}

The phenomenon of ownership, in the modern world, is seen as a most fundamental human right. In fact, the right to ownership in Turkey is also located under the protection of Article 35 of the Constitution of the Turkish Republic. Ownership rights give usage rights to the owner of the property, as explained in the law. However, this right can be restricted for the public's benefit and for legal regulation. The reason for these restrictions is provision of services such as education, health, transportation, culture, and sports (Gölcüklü, 2017: 11).

Expropriation brings significant changes; however, it causes many families to leave their original places of residence and to experience problems. People are forced to stay away from their natural environment within which they had built social institutions, maintained their culture, manufactured their products, made a living, and socialized. Therefore, the socio-spatial development in its natural state gets interrupted and socio-spatial relations are transformed (Konak, 2002: 82; Wei, 2011; Sargeson, 2013).

For those, living in the countryside, losing agricultural fields clearly means losing their basic financial security. Farmers, whose land has been expropriated, have to migrate and work in non-agricultural sectors (Wei, 2011: 513). While landowners try to resist the state's expropriation in some implementations (Feldman \& Geisler, 2019: 588; Cao et. al., 2008: 22), in others expropriation can be met with silence (Steur \& Das, 2009: 68-69). The kind of investment over the expropriated land affects the people's responses toward expropriation. In some cases, investments made after expropriation, are able to create new job opportunities for the villager (Yang \& Ho, 2019: 588). Agricultural lands, particularly in rapidly industrializing countries like China and India, are expropriated for industrial projects and urban real estate development, and this situation opens the way to versatile results in the countryside (Ghatak \& Mookherjee, 2014: 303). For example, approximately 40-50 million people in China are said to have lost arable agricultural land through expropriation and to have had to work in non-agricultural sectors (Wei, 2011: 513).

The Turkish Government usually offers two options to villagers, who face their land being expropriated: (1) compensation for expropriation, (2) provision of new land. The Government uses objective and subjective criteria for the expropriation costing. In addition to these two criteria, mixed systems are also found in which both criteria are used together (Tanrıvermiş et al., 2002: 112). When analyzing studies regarding expropriated villages in Turkey, expropriation is seen to bring many problems with it, such as migration, infrastructure, transforming the production structure, and socio-cultural disengagement (Orhan \& Gök, 2016; Bakırcı, 2016; Konak, 2002; Koday, 2013; Şahin, 2000; Şatıroğlu, 2012. Öner, 2004; Tunç, 2013). 
As suggested in these studies, some villagers receive expropriation compensation for their land, if their land has been expropriated. Expropriation significantly changes the socio-economic structure in villages. Villages' demographic structures also change, and village populations are reduced by almost half. Those, who belong to rural areas, prefer to migrate to cities where their relatives reside. Families, who only spend summer in the village, come to live in the city rest of the year. Some families spend the money that they receive in exchange for their land on constructing a home in their newly established villages. When assessing basic expenditures and household strategies, many more villagers are seen to have become consumers rather than producers (Orhan \& Gök, 2016: 142-143). Therefore, considering expropriation as an important socio-spatial intervention that affects villagers' futures would not be wrong.

\section{Research method}

\subsection{Research model}

In this research, a case study which is one of the qualitative methods was conducted. The process that the event of expropriation leads to in the village is considered able to be analyzed in-depth using the case study.

The first of the research hypotheses is that rural expropriation precipitates the process of terminating subsistence production. The second hypothesis is that rural expropriation leads to immigrating to cities and resolving social relations in the countryside. Another hypothesis is that villagers come from the position of manufacturer to the position of consumer as a result of expropriations that occur in the form of cash payments.

\subsection{Participants}

The research data have been collected from Demirci village residents who've become landless through the process of expropriation. Pre-field examinations have been done in the village, and around 150 people's fields are determined to have been expropriated; around half of these people are landowners though inheritance and have been identified as people who have no interest in farming and continuously live in the city.

The sample size in qualitative research is affected by many factors such as research topic and purpose and changes accordingly (Neuman, 2004: 161). The sample of the study consists of 20 people whose land has been expropriated. Five of the interviewees are women and 15 of them are men. All the women, who have participated in the interview, are widows and all the men are married. The youngest participant is 40 and the oldest is 73 years old. The participants' average age is 58 . When examining educational status, 15 participants have received primary school education, four have received high school education; and one, undergraduate education.

Most of the participants receive pensions in addition to many other forms of income. In total, 14 interviewees receive a pension. Of those receiving a pension, only three rented their land. The others, on the contrary, have engaged themselves in agriculture. Four interviewees have obtained income from a trade in addition to agriculture. Six interviewees earn income from both husbandry and agriculture. Only one interviewee's sole income is from farming. While 2,084 acres of land in total were expropriated, 2,148 acres of land were not expropriated. References made to the participants have been done by specifying participant number in order interviewed, gender, and marital status in parentheses in the text. 


\subsection{Data collection}

The interview technique has been used in the field research. Interviews were held with five villagers before forming the interview questions. In addition, observations were made in the village, and the fields and pastures where the expropriated lands are found have been visited. The semi-structured questionnaire form has been formed based on pre-field interviews, the notes taken from the observations, and the literature review.

The interviewed villagers have been asked about their demographic information, their relations with agriculture and animal husbandry, how much of their land is available, their attitudes toward expropriation, their attitudes toward the material compensation paid for expropriation, how they use the expropriation compensation, their perceptions on the socioeconomic change that expropriation have caused, and their expectations related to the future of their village and agriculture.

For sampling, the qualitative research has used purposeful sampling. The interview list was created in line with the information obtained from the pre-interviews done in the village. People, who have resided in the village, prior to the expropriation have been focused specifically in this study. The application stage of the research has been conducted between $6^{\text {th }}$ July and $9^{\text {th }}$ July, 2019. The participants have been provided with information about the study prior to the interview, and consent has been received for using a voice recorder to record the interview.

\subsection{Data analysis}

The case and individuals are described primarily in case analysis and then problems and themes are analyzed (Cresswell, 2017: 196). Thematic analysis allows one to focus on describable life and behavioral patterns. Thus, the themes that emerge from the participants' stories are brought together to form a comprehensive picture of their common experiences (Aronson, 1994: 1-2).

The data obtained from the voice recordings have been encoded for data analysis. All encoded interviews and notes related to the field observations have been read. The encoded interviews have been analyzed in the program MAXQDA. In the coding, similar topics have been brought together and the topics have been abbreviated as codes (Creswell, 2017: 198). Thus, the emerged themes have been analyzed by associating them with the literature.

\section{Findings}

\subsection{A village whose land has been expropriated: Demirci}

The village of Demirci, where the research has been carried out, is located in Eskişehir's Sivrihisar district. The village is off of the Eskişehir-Ankara Highway $33 \mathrm{~km}$ from Sivrihisar, $133 \mathrm{~km}$ from Eskişehir, and $32 \mathrm{~km}$ from Ankara's Polatl district. Demirci has been established on top of a hill. The village has a hot and dry climate during summer and weather turns cold in the winter here. The lands are steppes, and dry farming (barley, wheat) is generally done. Irrigation farming can be done in a very small area that is watered by artesian wells. One of the basic sources of income is sheep and goat farming. The village has a primary school that has been unused for a long time, lodgings for two teachers, a health center, and a sanatorium. In addition, the village has a drinking water system and a post office. Access to the village is provided by two roads, one asphalt road and the other a gravel road (Sivrihisar Sosyal Kültür \& Dayanışma Derneği, 2019). 
The population of the village was 641 in 1965, 626 in 1980, 550 in 1990, 323 in 2000, and 210 in 2010. The population of the village, which was 168 in 2015, was determined as 156 when coming to 2018 (TurkStat, 2019).

In 2017, the inhabitants of Demirci have faced land expropriation because of authorities' efforts to move the military from Ankara to the border of the Polatl and Sivrihisar districts (Hürriyet Gazetesi, 2019). According to the interviewees' response, a large portion of the village's arable lands has been expropriated. ${ }^{2}$ Furthermore, interview data suggests that the rate of arable agricultural land has decreased considerably after the second expropriation of land.

The demographic structure is stated to have changed significantly after the expropriation in the village. The village leader did not give any clear information on this issue. The interviewees stated that 20 households live in the village all year round. A significant portion of these are those engaged in animal husbandry.

\subsection{Responses to expropriation and the developed household strategies}

The village's expropriated lands were stated to have low-productivity. Seven respondents were in favor of the expropriation, especially due to the inefficiency of the expropriated land. These interviewees' poor financial situation prior to the expropriation made it attractive to them because of the income they were taking in. Nine interviewees assessed the expropriation negatively. The interviewees' assessment that land ownership is a necessity for their continued survival appears as the main reason they didn't accept expropriation.

Now they have taken our future this way; that's why I didn't want it. I mean, now we can't leave anything for our kids to inherit. We will leave an empty life in front of them, nothing at all. For example, we will say that you have school or else you are someone else's slave. But even if we had our own land, the children would stay here even if hungry and thirsty (\#15, Man, 59).

The state had expropriated the village pastures prior to expropriating their agricultural land. Expropriation of the pastures was generally perceived negatively by the villagers who earn their livelihood with animal husbandry.

I think, the expropriation shouldn't happen because I'm dealing with sheep; I mean it hurt me. My pastures are gone I can't raise livestock (\#7, Man, 50).

The expropriation occurred in the village by giving the expropriation compensation as cash. The research participants were asked how they would evaluate being given land instead of the expropriation compensation. Some of the participants stated not wanting to go anywhere other than their village when facing this question. Another section said they could move to new fields, on the record "having fertile lands," because they know nothing but farming and have the agricultural tools and machines. Some participants stated not wanting to be given other lands because they are old, because they have not kids interested in farming, or because they need the money.

It is seen that expropriation of lands and pastures in the village negatively affects the sustainability of agriculture and animal husbandry. The villagers are unable to predict what to do when faced with diminished lands. However, quite a few mentions that agriculture and animal

\footnotetext{
${ }^{2}$ According to information given by an interviewee who had previously taken part in village administration, the village has a total of 75,000 quarter-acres of land, including pastures, settlement units, and arable and non-cultivated lands. Of this land, the state has expropriated approximately 31,600 quarter-acres. Within the 31,600 quarter-acres of expropriated land are around 14,270 quarter acres of pasture land (\#17, Man, 40).
} 
husbandry would have no future if there is no expropriation. According to the interviewees, no new generation has been produced that will maintain the fields and livestock. In particular, the children born in the village, begin living in urban areas at young age for their education, resulting disruption in the village's processes of reproduction. Young people prefer urban living and they are unable to be completely included in the traditional learning and social reproduction processes (Bıçkı, 2011). This situation deteriorates the relationship between production and social reproduction (Katz, 1991).

Since there is no young generation in the village, agriculture may end completely in the future. It's not the generation ending (\#19, Man, 62).

In addition to not producing new generations, changes in climate conditions, the unprofitability of lands, and the occurrence of the relatively high cost of agricultural inputs in Turkey do not make agricultural and animal production sustainable in villages based on subsistence production. On this point, expropriation is seen as an accelerating factor in the sustainability of agriculture and animal husbandry in terms of time.

The villagers have given various responses on the issue of whether or not the compensation for expropriation that the state paid the villagers reflected the real value of the land. Some participants have stated that the material value has been much lower prior to their land being expropriated, and others have been able to receive higher compensation and mention that they have received good compensation from the state. Still others state that the village has been seriously damaged as a result of having the military included in the land, especially within the areas of expropriated pastures, and they could not establish any business with the given compensation, and that their future has been taken away.

While livelihoods based on sheep and goat farming has occurred in the past in villages, the number of people involved in animal husbandry these days has considerably decreased. One interviewee states that 10 people remained interested in sheep and goat farming, and that the number of animals is approximately 2,000. The interviewees, who have done steer breeding, state having to sell their animals when permission wasn't given to enter the pastures. The participant's statement, below, perfectly explains the process regarding the expropriation of the pastures and the villagers' response to it.

First, they (the state) already expropriated the pastures. State officials asked the peasants to approve the expropriation of the pastures. All the villagers approved the expropriation of the pastures. The pastures were expropriated, afterward they expropriated the fields... Later, everyone regretted it. The animal farmers also didn't want it... Once the pastures were expropriated, expropriating the fields was just easy (\#11, Man, 48).

"If your land had never been expropriated and someone wanted to come and buy your land for the same value, would you sell?" A section of the villagers responded to the question saying they would not sell their land because it is a source of income for them and it has a valuable presence that can be left as an inheritance in the future. Those, who say that they would sell based these thoughts on reasons such as not having fertile soil, the toil of farming not bringing in income, old age, and no generation remaining to toil in the fields.

Only four interviewees have lived in the village during winters and the city in summers prior to expropriation. Sixteen participants permanently reside in the village. These figures change after expropriation. Eight interviewees have migrated with their family to the city and now only spend summer months in the village and winter months in the city. The other eight interviewees permanently live in the village.

Seventeen of the participants have bought houses with their expropriation compensation that has been given as cash in Ankara's Polatlı District, in Eskişehir, or in Ankara 
$(108 \mathrm{~km}$ ), which have respective distances of $32 \mathrm{~km}, 133 \mathrm{~km}$, and $108 \mathrm{~km}$ from the village. Most of these residences were bought for the purpose of "use value." Their preference for such an investment can be explained by: (1) villagers who have lost land primarily preferring places where their fellow townsmen are, (2) wanting to still continue agricultural work in the village, and (3) desiring to stay in touch with the village.

Aside from buying a home in the city with part of the money they have received, a section of the villagers has been found to act in certain ways such as paying debts, buying a new car or fixing up their current car, replacing the furniture in the house, doing maintenance to their village home or building a new home, and giving their children financial assistance. Therefore, a significant portion of the interviewed people could not become entrepreneurs, could not establish a business in the city, and could not buy land or live stocks in their village. They have inclined to invest in housing without a significantly productive return. When asked the reasons villagers invested their compensation they have received from expropriation in housing, a portion of the villagers stated that because they didn't receive the money at once but at two different times, they spent the money in different ways each time. Some participants mention that they are not being able to make an income-generating investment because of the scarceness of the money. Some of those, whose land has been expropriated, mention that they are not being able to start new work because of being old or not knowing any work other than farming.

Only two interviewees state that they have not made any investment yet with all the money they have received. One interviewee has started cattle breeding by combining the expropriation compensation with earlier savings in order to do animal husbandry in the village. The two interviewees have gotten a commercial vehicle in the city.

The village has the expectation of a second expropriation. A significant portion of the participants doesn't want the entire village to be expropriated. Another portion of the villagers stated that, while leaning towards continuing the expropriation of lands that were dry farmed, they had not wanted the lands that were settled and the portion that was suitable to irrigated agriculture to be expropriated. The basic reason for not wanting the village's settled areas and irrigated agricultural lands to be expropriated can at least be explained by the desire to maintain the ancestral relations in the village and thus through the emotionality that the presence of a village and a past invoke.

We live and die here. I don't want the village to go. (\#2, Woman, 73)

When questioning change in the village economically, most of the interviewees stated people had bought homes and migrated from the village.

Everyone bought a new car. They changed their cars, bought homes in the city, and renovated their houses in the village (\#12, Woman, 66).

Some of the participants have renovated their homes after the expropriation. This case is in fact an indicator that their hope from the village hadn't been completely cut. However, the point that social relations have come to shows social disintegration to have occurred. A significant number of participants stated migrating to the city because of animal husbandry reaching the end of the line and arable land being reduced. Additionally, because of villagers being old and their children choosing not to live in the village, they felt concerned about the future of the village.

(Will your children continue your line of work?) They don't get it; no one is left who can. We are the last generation. We are the last generation to deal with livestock. We can't find anyone after us (\#17, Man, 40). 


\section{Discussion}

Studies in the field of Turkish rural sociology since the foundation of the Republic of Turkey have addressed various political practices such as statism, protectionism, liberalization, national development, being open to global markets, and local/regional development (Nerse, 2014: 165; Ecevit et al., 2009: 47-48). Sociological studies taking on the subject of expropriations (especially due to dam constructions) that occurred as a result of policies for rural development have mostly addressed the consequences of forced migration and resettlement (Şatıroğlu, 2012; Tunç, 2013; Öner, 2004; Orhan \& Gök, 2016). In the international literature, researches on the forced migration and relocation caused by expropriations applied in underdeveloped countries (Feldman \& Geisler, 2012) and on the social problems caused by the expropriations aimed at development particularly in industrialized countries such as China and India have drawn attention (Ghatak \& Mookherjee, 2014; Fernandes \& Raj, 1992; Sargeson, 2013; Wei, 2011).

The common thread observed in the studies in the literature is that the expropriation process leads to changes in social relations, household structures, stratification, production and consumption patterns in addition to social unrest and corrosive relations with public institutions (Konak, 2002; Tunç, 2013; Şatıroğlu, 2012; Sargeson, 2013; Wei, 2011). Furthermore, expropriation affects people psychologically and leads to anxiety and stress for the future (Şatıroğlu, 2012).

In the case of Demirci village, there was no forced migration and resettlement. A significant number of villagers eagerly approved the expropriation and voluntarily migrated from the village to the city, although they had lands that were not expropriated and the residences in the village. This result makes sense only in a social and cultural context (Wallace, 2002).

When the data obtained in the example of Demirci village were examined, it is determined that those who leased their fields and those who had constantly stayed in the village under the burden of agricultural debt desired expropriation. Some villagers, on the other hand, have relied on the expropriation cost and easily approved the expropriation of the pastures of the village, since a new generation to stay in the village could not reproduce. It is considered that these results may be associated with the effect of rural and agricultural policies in Turkey on the villages producing for subsistence. (Pamuk, 2009; Keyder \& Yenal, 2011; Ecevit et al., 2009). However, the fact that those who continued their subsistence especially through ovine breeding and those involved in agricultural production by coming to the village in summer months although living in the city did not want the expropriation also draws attention. For these people, land is seen to mean assurance (Wei, 2011: 513).

Expropriation accelerated the process of social dissolution that has occurred through migration to cities and modern life that has entered the villages after 1980. Similar to the literature, with the expropriation, the decrease in the number of households staying in the village in the winter months and the fact that those who moved to the city came to the village for a short time leads to further dilution of the relations and the dissolution of the primary relations (Konak, 2002; Wei, 2011). Additionally, as seen in other samples, villagers evaluated the expropriation price they received with non-income-generating expenses such as housing investment, car and furniture purchasing in the city instead of investing in profitable areas (Şahin, 2000: 85; Orhan \& Gök, 2016).

Briefly, when the household strategies of the villagers faced expropriation are evaluated, these have been determined that (1) the villagers who'd been made landless tend to migrate to the city, (2) the financial provision obtained from expropriation is generally used in non-productive ways, and (3) a social dissolution is experienced. 


\section{Acknowledgements}

This research did not receive any specific grant from funding agencies in the public commercial, or not-for-profit sectors.

The author declares no competing interests.

\section{References}

Aronson, J. (1994). A pragmatic view of thematic analysis. The Qualitative Report, 2(1), 1-3.

Bakırcı, M. (2016). Barajların mekânın yeniden organizasyonuna etkileri: Melen barajı örneği [The effects of dams on the spatial reorganization: The case of Melen dam]. Marmara Coğrafya Dergisi, (33), 439-464.

Bıçkı, D. (2011). Türkiye kırsalında yoksulluk sorunu: Çanakkale Kocalar köyü örneği [Rural poverty problem in Turkey: Çanakkale Kocalar village example]. Uludağ Üniversitesi İktisadi ve İdari Bilimler Fakültesi Dergisi, 3o(1), 161-180.

Cao, G., Feng, C., \& Tao, R. (2008). Local land finance in China's urban expansion: Challenges and solutions. China and World Economy, 16(2), 19-30. https://doi.org/10.1111/j.1749-24X.2008.00104.x

Cresswell, J. (2017). Araştırma deseni: Nitel, nicel ve karma yöntem yaklaşımları (3. Baskı) [Research design: qualitative, quantitative, and mixed methods approaches]. Ankara: Eğiten Kitap.

Ecevit, M., Karkıner, N., \& Büke, A. (2009). Köy sosyolojisinin daraltılmış kapsamından, tarım-gıda köylülük ilişkilerine yönelik bazı değerlendirmeler [Some evaluations on agriculture-food peasant relations from the constricted scope of village sociology]. Mülkiye, 33(262), 41-62.

Feldman, S., \& Geisler, C. (2012). Land expropriation and displacement in Bangladesh. The Journal of Peasant Studies, 39(3-4), 971-993. https://doi.org/10.1080/03066150.2012.661719

Fernandes, W., \& Raj, A. (1992). Development, displacement and rehabilitation in the tribal areas of Orissa report. New Delhi: Indian Social Institute.

Ghatak, M., \& Mookherjee, D. (2014). Land acquisition for industrialization and compensation of displaced farmers. Journal of Development Economics, 110, 303-312. https://doi.org/10.1016/j.jdeveco.2013.01.001

Gölcüklü, M. (2017). Acele kamulaştırma [Rush expropriation]. Ankara: Seçkin Yayıncılık.

Hajdu, F. (2006). Rural livelihood strategies in Eastern Cape, South Africa. Linköping: Department of Water and Environmental Studies, Linköping University.

İçduygu, A., Sirkeci İ. \& Aydıngün İ. (1998). Türkiye'de iç göç ve iç göçün işçi hareketlerine etkisi, Türkiye’de içgöç [The internal migration in Turkey and the effect of internal migration on worker movements.]. İstanbul: Tarih Vakfı Yayınları, pp. 207-244.

Katz, C. (1991). Sow what you know: The struggle for social reproduction in rural Sudan. Annals of the Association of American Geographers, 81(3), 488-514.

Kayıkçı, S. (2004). Cumhuriyet'in kuruluşundan günümüze kadar köye ve köylüye yönelik olarak izlenen politikalar [Policies followed to the village and the villagers from the foundation of Republic of Turkey to the present]. Türk İdare Dergisi, (448), 1-22.

Keyder, Ç., \& Yenal, Z. (2011). Agrarian change under globalization: Agrarian change under globalization. Journal of Agrarian Change, 11(1), 60-86.

Koday, Z. (2013). Yeri değiştirilen köy yerleşmelerine örnek: Aşağı Çat, Yukarı Çat ve Taşağıl köyleri [Examples of Villages which are Translocated: Aşağı Çat, Yukarı Çat and Taşağıl]. Atatürk Üniversitesi Sosyal Bilimler Enstitüsü Dergisi, 17(1), 223-238. 
Konak, A. (2002, Mayıs). Sosyal Antropolojik Yaklaşımla Yeniden Yerleştirme Uygulamalarının Karşılaştırmalı İncelenmesi (Yenisamsat, Reyhanlı/Vazvaza, /Yalıköy Örnekleri) [A comparative examination of practices of resettlement from perspective of social anthropology]. C.Ü. Sosyal Bilimler Dergisi, 26(1), 81-100.

Moen, P. \& Wethington, E. (1992). The concept of family adaptive strategies. Annual Review of Sociology, $18,233-251$.

Nerse, S. (2014). Türkiye kır çalışmalarında paradigma değişimi [Paradigm shift in the Turkish rural studies]. Sosyoloji Dergisi, 3(29), 165-179.

Neuman, W. (2004). Basics of social research: Qualitative and quantitative approaches. Boston: Pearson Education.

Orhan, F., \& Gök, Y. (2016). Baraj yapımı nedeniyle yeri değiştirilen yerleşmelere örnek: Oruçlu ve Zeytinlik köyleri (Artvin) [Construction of the dam due to the Replaced Settlement Place Example: Fasting and Olive Villages (Artvin)]. Doğu Coğrafya Dergisi, 21(35), 131-148. https://doi.org/10.17295/dcd.58254

Öner, İ. (2004). Kadınların Kırdan Kente Yeniden Yerleşime Cevabı: Elazığ'da Keban barajı kadın göçmenleri örneği [Women's response to rural-urban resettlement: A case study of Keban Dam Female Migrants in Elazı̆̆]. Ph. D. diss., Firat University.

Öztürk, M., Topaloğlu, B., Hilton, A., \& Jongerden, J. (2018). Rural-urban mobilities in Turkey: Sociospatial perspectives on migration and return movements. Journal of Balkan and Near Eastern Studies, 20(5), 513-530. https://doi.org/10.1080/19448953.2018.14066

Pamuk, Ş. (2009). Türkiye'de tarım ve iktisadi gelişme: 1880-200o [Agriculture and economic development in Turkey: 1880-2000]. Mülkiye, XXXIII (262), 63-76.

Redclift, M. (1986). Survival strategies in rural Europe: Continuity and change. Sociologia Ruralis, 26(3/4), 15-27.

Sargeson, S. (2013). Violence as development: Land expropriation and China's urbanization. Journal of Peasant Studies, 4o(6), 1063-1085. https://doi.org/10.1080/03066150.2013.865603

Steur, L., \& Das , R. (2009). What's left? Land expropriation, socialist “modernizers," and peasant resistance in Asia. Focaal- European Journal of Anthropology, (54), 67-72. https://doi.org/10.3167/fcl.2009.540105

Şahin, K. (2000). Altınkaya baraj gölü suları altında kalan köylerden göç edenlerin karşılaştıkları sorunlar ve Vezirköprü şehrine etkileri [Problems of migrants from villages due to Altınkaya dam and their effects on the city of Vezirköprü]. Osmangazi Üniversitesi Sosyal Bilimler Dergisi (Special Issue), 85-99.

Şatıroğlu, K. (2012). Zorunlu göç ve yeniden yerleşimin toplumsal çevre üzerindeki etkisi: Tahtah barajı örneği [Land versus Cash versus No Compensation: Long-Term Socio-Economic Impacts of Tahtali Dam in Turkey]. Ph. D. diss., Ankara University.

Şenol, E. (2018). Kırdan kente göçün kırsal alanlara etkileri: Boraboy köyü örneği (Amasya Taşova) [The effects of migration from rural to urban on to rural areas: the example Boraboy village (Amasya-Taşova)]. Uluslararası Sosyal Araştırmalar Dergisi, 11(55), 407-421. http://dx.doi.org/10.17719/jisr.20185537210

Tanrıvermiş, H., Gündoğmuş, E., Birinci, A., \& Ceyhan, V. (2002). Türkiye'de tarım arazilerinin kamulaştırma bedellerinin tespitinde karşılaşılan sorunlar ve çözüm yolları [Problems and their solutions for valuing of farmland for condemnation in Turkey]. Türkiye $V$ Tarm Ekonomisi Kongresi, pp. 111-123. Erzurum.

Tunç, İ. (2013). Sivas ili Hafik ilçesi Pusat barajı yapımından etkilenen nüfusun yeniden yerleştirilmesi ve uyum sorunlarının sosyal kültürel antropolojik açıdan incelenmesi [The resettlement of the population affected by the construction of the Pusat Dam, located in Hafik of Sivas city, and the exploration of this population's integration problems from social, cultural and anthropological views]. MA thesis, Cumhuriyet University. 
TurkStat. (2019). Municipal, village and neighborhood populations. Retrieved 4 March 2019, from https://biruni.tuik.gov.tr/medas/?kn=95\&locale=tr.

Wallace, C. (2002). Household strategies: Their conceptual relevance and analytical scope in social research. Sociology, 36(2), 275-292. https://doi.org/10.1177/0038038502036002003

Wei, Z. (2011). Rural elderly in contemporary China: A case study of a village in Jiangsu Province. Marriage \& Family Review, 47(8), 511-528. https://doi.org/10.1080/01494929.2011.622071

Yang, X., \& Ho, P. (2019). Is mining harmful or beneficial? A survey of local community perspectives in China. The Extractive Industries and Society, (6), 584-592. https://doi.org/10.1016/j.exis.2019.02.006 